\title{
Shareholder Protection And Forecast Bias
}

Seung-Woog (Austin) Kwag, (Email: austin.kwag@business.usu.edu), Utah State University

\begin{abstract}
This research explores whether shareholder protection influences analyst optimism and forecast accuracy in a global setting. The first set of empirical results suggests that, as commonly observed in the existing domestic literature, analyst optimism characterizes analysts' forecasts in the 19 sample countries. Further empirical results provide evidence that analyst forecasts issued in countries with strong shareholder protection laws are less optimistic and more accurate than analyst forecasts published in countries with weak protection laws. It is also observed that analyst forecast is superior to a naïve model of no change in earnings. (JEL: G15, G18)
\end{abstract}

\section{INTRODUCTION}

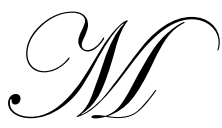

any studies have examined analysts' earnings forecasts. Some conclude that analysts' forecasts tend to exceed actual earnings performance (Butler and Lang, 1991; Abarbanell, 1991; Ackert and Athanassakos, 1997), while others explore more complex hypotheses about how analysts respond to new earnings information. Among the latter are La Porta (1996) and Easterwood and Nutt (1999), who establish a connection between analyst optimism and under- and overreaction to new earnings information. On the other hand, Keane and Runkle (1998) argue that analysts make rational forecasts. They challenge some of the earlier findings, concluding that they suffer from methodological flaws that result in findings of "irrationality" - e.g., analyst optimism.

The extant analysis of analysts showing systematic behavioral tendency overlooks an important institutional factor: shareholder protection, which is measured by the shareholder rights such as one share-one vote, proxy by mail, and preemptive rights to new issues. Recently, Hung (2001) and Hope (2003) report that shareholder protection reduces earnings manipulation and uncertainty in earnings forecasts. Reductions in earnings manipulation and forecast uncertainty are, in turn, likely to reduce analyst optimism and improve forecast accuracy. This paper extends prior studies by investigating the relationships between analyst optimism and shareholder protection and between forecast accuracy and shareholder protection in a global setting. I assess the country-specific levels of legal shareholder protection for 19 foreign countries and directly relate them to two bias variables (optimism and accuracy) that are affected by the forecasting behavior of analysts. Understanding the relationships of shareholder protection with analyst optimism and accuracy provides insights into the impact of regulatory policies on earnings forecasts and eventually on security valuation.

As in other studies, I draw on the classification scheme of La Porta, Lopez-De-Silanes, Shleifer, and Vishny (1998) and classify the sample countries into two groups based on the degree of legal shareholder protection (Hung, 2001; Hope, 2003). Based on this classification, I test the hypothesis that analysts in the strong shareholder-protective countries issue less biased - i.e., more accurate and less optimistic - earnings forecasts than those in the weak shareholder-protective. The empirical findings are supportive of this hypothesis. In addition, I examine the relative performance of analysts' forecasts against a naïve forecasting model and find that analyst forecast is superior.

Table 1: Portfolio Formation Based On Shareholder Protection

The portfolio "strong" stands for strong shareholder protection, while the portfolio "weak" denotes weak shareholder protection.

\begin{tabular}{|c|c|}
\hline Shareholder Protection Portfolio & Countries \\
\hline Strong & $\begin{array}{c}\text { Canada, Hong Kong, India, Malaysia, Singapore, South } \\
\text { Africa, United Kingdom, Japan, Chile }\end{array}$ \\
\hline Weak & $\begin{array}{c}\text { Belgium, Germany, Indonesia, Italy, Mexico, Netherlands, } \\
\text { Turkey, Austria, Switzerland, Denmark }\end{array}$ \\
\hline
\end{tabular}


This paper contributes to the existing literature on analyst forecasting behavior in three ways. First, it presents evidence that investor protection is an important factor influencing analyst forecast bias and extends the previous studies that simply focus on prevalent analyst bias in earnings forecasts. Second, by using the individual earnings forecasts compiled from the I/B/E/S database, I generate a set of aggregate earnings forecasts and estimate the median forecast for actual earnings of a firm as opposed to using the $\mathrm{I} / \mathrm{B} / \mathrm{E} / \mathrm{S}$ consensus earnings forecasts. This process reduces potential bias due to the publication lag from using the consensus forecasts (O'Brien, 1988). Third, to mitigate the problem of misspecification, I control for analyst coverage, bias persistence, country, time, and industry effects, and forecast dispersion.

\section{PRIOR STUDIES}

An extensive body of prior literature suggests that optimism is a typical characteristic of the U.S. analysts' earnings forecasts. For the period from 1981 to 1984, Abarbanell (1991) documents that the average consensus forecast is optimistic, and that the number of optimistic forecasts surpasses that of pessimistic forecasts. Analyzing the characteristics of individual analysts' earnings forecasts, Butler and Lang (1991) find that individual analysts are persistently optimistic in relation to median consensus forecasts. La Porta (1996) shows that analysts tend to issue upward-bias earnings forecasts for growth stocks. Kwag and Shrieves (2005) further find that, although analyst optimism seems to be a characteristic of earnings forecasts, both persistent optimism and pessimism can be successfully formed on the basis of the historical information on consensus forecast errors. Ang and Ma (1999) add international evidence of analyst optimism. They document that the aggregate analyst optimism of Chinese shares is about twice that of Hong Kong companies' shares. With respect to analyst optimism, they compare Chinese shares with those of other Pacific Basin countries such as Japan, Malaysia, Singapore, South Korea, Thailand, Taiwan, Philippines, and the U.S., and show that the analyst optimism of Chinese shares is much higher than that of any other Pacific Basin country. In sum, analysts, as a group of market participants, appear to issue optimistic forecasts and the level of optimism seems to differ across countries.

Two recent studies investigate the associations between shareholder protection and earnings manipulation, and between shareholder protection and analyst forecast accuracy (Hung, 2001; Hope, 2003). Hung (2001) finds evidence that earnings manipulation weakens in strong shareholder protection environments. He indirectly tests the hypothesis that strong shareholder protection discourages managers from manipulating earnings and thus will eventually increase the value relevance of analysts' earnings forecasts. He finds that there is a significant association between shareholder protection and the value relevance of earnings. Investigating the effects of variations in enforcement of accounting standards on analyst forecast accuracy, Hope (2003) reports that strong enforcement of accounting standards, in part reflective of strong shareholder protection, reduces uncertainty in earnings forecasts and improves analyst forecast accuracy. The regressions of forecast accuracy on enforcement and various control variables show significantly positive parameter estimates of enforcement at the $1 \%$ level.

In line with the Hope's study, the current research investigates the forecasting behavior of international financial analysts in relation to shareholder protection. Different from the Hope's study, it directly relates both analyst optimism and forecast accuracy to shareholder protection. This topic is important because financial analysts are one of the major forces to form the market expectations about security prices, yet the presence and levels of shareholder protection vary across countries. Thus, an interesting question emerges naturally: does shareholder protection moderate analyst optimism and enhance forecast accuracy?

\section{PORTFOLIO FORMATION AND HYPOTHESES DEVELOPMENT}

Countries have various legal systems to protect shareholders. Some provide stronger protection of investors than others. La Porta et al. (1998) rank countries based on the existence of legal rules such as one share-one vote, proxy by mail, shares not blocked before a shareholders' meeting, cumulative voting or proportional representation, oppressed minorities mechanism, and preemptive rights to new issues. Countries are considered shareholderprotective if the company law or commercial code of the country (1) requires that ordinary shares carry one vote per share; (2) allows shareholders to mail their proxy vote to the firm; (3) does not prevent shareholders from selling shares for a number of days prior to a general shareholders' meeting; (4) allows cumulative voting for directors or 
proportional representation on the board that gives more power for minority shareholders to put their representatives on boards of directors; (5) grants minority shareholders the right to challenge the directors' decisions in court; or (6) offers shareholders the preemptive right to buy new shares so that they are protected from dilution.

Drawing on the classification scheme of La Porta et al., I construct two testable portfolios of countries strong and weak. The portfolio "strong" stands for the strong shareholder protection, while the portfolio "weak" denotes the weak shareholder protection. If a shareholder protection rule exists in the country, I assign a binary numeric value to the country. A binary variable is equal to one if the country incorporates the corresponding legal rule to the company law or commercial code, and zero otherwise. Thus, if a country possessed all the rules effective in its jurisdiction, the score of shareholder protection would be six, indicating very strong shareholder protection. There is, however, no country with a shareholder-protection score of six. This means that every country in the sample misses at least one of the six rules. Note, however, that no one specific rule is systematically missing across countries. If a country does not have any of the six rules incorporated in its commercial code (i.e., it has a shareholder-protection score of zero), it is considered a country with very weak shareholder protection. As a result, the score of shareholder protection ranges 0 to 5 . The countries with the shareholder-protection scores 4 and 5 are assigned to the strong portfolio, while countries with the scores 0 and 1 are assigned to the weak portfolio (see Table 1).

Investors in the strong portfolio can actively participate in voting for new directors. Their shares are well represented in shareholders' meetings even though they are minorities. It is easier for them to call an extraordinary shareholders' meeting on special issues. In addition, managers in the strong portfolio are less prone to manage earnings and more inclined to distribute the firm's true earnings information. Accordingly, analysts tracking firms in a strong shareholder-protected system are likely to issue less biased earnings forecasts than do those in a weak system.

From these expectations, I derive two hypotheses: First, analysts issue more accurate earnings forecasts when shareholders are strongly protected by the law, since managers have fewer opportunities to manipulate earnings and shareholder protection reduces uncertainty in earnings forecasts. Second, analysts are less optimistic when they forecast earnings under the strong shareholder-protected law, probably because analysts have stronger incentives to affect security prices through monitoring and forecast improvements.

\section{Data}

The source of data is the $\mathrm{I} / \mathrm{B} / \mathrm{E} / \mathrm{S}$ International database. Since it is well documented that consensus earnings forecasts in the I/B/E/S Summary tape contain "stale" forecasts which may bias the empirical tests, I use individual analysts' forecasts compiled in the I/B/E/S Detail tape. Following O'Brien (1988), I create a set of aggregate earnings forecasts with a 90-day window. I start with the annual earnings announcement date and then retrieve individual forecasts that have a date prior to that. I use a "window" of 90 days of the announcement date to collect individual forecasts that will be used to estimate the median forecast for actual earnings of a firm. For example, if the actual earnings were announced on March 31, I would use an interval from January 1 to March 30 as the window within which I would collect individual forecasts. If there were two or more forecasts from the same analyst during the 90day period, I would only use the latest one. Then I calculate the median and standard deviation among all the individual analysts' forecasts that meet the dating criterion.

The final sample consists of the median earnings forecasts of individual analysts and actual annual earnings for international firms covering 19 countries during the period 1989-2003. The sample size is 50,707 firm-years (11,279 international firms). Lang, Lins, and Miller (2003) state that cross-listed firms are associated with greater analyst coverage and increased forecast accuracy. Thus, cross-listing is a potential confounding variable that may affect analyst optimism and forecast accuracy. Therefore, I identify firms listed on the U.S. exchanges - NYSE, AMEX, or NASDAQ - by obtaining this information from the Center for Research in Security Prices (CRSP) database. The sample contains 273 cross-listed firms (1,415 firm-years), representing $2.4 \%$ of the sample size. 


\section{Bias Measures}

As in Ang and Ma (1999), I employ three measures of analyst forecast bias: (1) the signed forecast error $\left(F E_{i, t}\right)$, scaled by the actual earnings; (2) the absolute forecast error $\left(|F E|_{i, t}\right)$, scaled by the actual earnings; and (3) the absolute forecast error, scaled by a change in actual earnings. The following describe the equations used to estimate the three different characteristics of analysts' forecasts.

$$
\begin{aligned}
& F E_{i t}=\frac{F_{i t}-A_{i t}}{\left|A_{i t}\right|} \\
& |F E|_{i t}=\frac{\left|F_{i t}-A_{i t}\right|}{\left|A_{i t}\right|} \\
& I N F O_{i t}=\frac{\left|F_{i t}-A_{i t}\right|}{\left|A_{i t}-A_{i, t-1}\right|}
\end{aligned}
$$

where $A_{i t}\left(A_{i, t-1}\right)$ is actual annual earnings in year $t(t-1)$ for firm $i, F_{i t}$ is the median forecast of individual analysts' forecasts in year $t$ for firm $i, F E_{i t}$ is the signed forecast error in year $t$ for firm $i$ scaled by actual earnings, and $|F E|_{i t}$ is the absolute value of analysts' earnings forecast errors in year $t$ for firm $i$ scaled by actual earnings, and INFO ${ }_{i t}$ is the information content of analysts forecasts. Note that actual earnings and analysts' forecasts are measured in local currencies and the country subscript is omitted.

$F E$ measures the degree of analyst optimism; $|F E|$ gauges the accuracy of analysts' forecasts; and INFO assesses the relative performance of analysts' forecasts against a naïve forecasting model - no change in earnings forecasts: $A_{i t}-A_{i, t-1 .}$. The naïve model suggests that the contemporaneous earnings per share $\left(A_{i t}\right)$ are best predicted by the previous earnings per share $\left(A_{i, t-1}\right)$. If the naïve model is true, INFO is equal to or greater than one. For instance, suppose that $A_{i t}$ turn out to be $\$ 0.2$, while $A_{i, t-l}$ was $\$ 0.1$. If the median analyst forecast were $\$ 0.25$, then $I N F O$ would be $(0.25-0.2) /(0.2-0.1)=0.5$, indicating that analysts' forecast is more accurate than the naïve-model forecasting.

\section{Preliminary Analysis}

The overall descriptive statistics in Table 2 confirm the domestic evidence of analyst optimism and the superior performance of analysts forecasts over the naïve model. The grand mean of forecast errors is 0.0989 and significant at the $1 \%$ level. The grand mean of the information measure (INFO; 0.4944) is less than one, meaning that analysts' forecasts outperform the naïve model. In addition, notice that there are about $12 \%$ of zero forecast errors, probably a suggestion of earnings management (Degeorge, Patel and Zeckhauser, 1999). The degree of earnings management seems to vary across countries with the percentage of zero forecast errors ranging from $2.94 \%$ (Japan) to $24.69 \%$ (Germany).

\section{Table 2: Overall Sample Statistics For FE And INFO}

This table presents overall descriptive statistics of contemporaneous forecast errors $(F E)$ and information content of earnings forecasts (INFO). POS\% is the percentage of positive analysts' forecast errors; $N E G \%$ is the percentage of negative analysts' forecast errors. Zero \% is the percentage of zero analysts' forecast errors. I use the median estimate of individual earnings forecasts to obtain forecast errors. This mitigates the impact of extreme values.

\begin{tabular}{|c|c|c|c|c|c|c|}
\hline & $\mathbf{N}$ & Mean & Median & POS\% & NEG\% & Zero\% \\
\hline FE & 50707 & $0.0989 * * *$ & 0.0000 & $43.74 \%$ & $44.32 \%$ & $11.94 \%$ \\
\hline INFO & 50707 & 0.4944 & 0.1639 & N/A & N/A & N/A \\
\hline
\end{tabular}


Table 3 shows the results of the binomial tests on individual portfolios, both strong and weak. The test statistic of the binomial test is "T." If "T" lies beyond the critical regions at each significance level, we reject the null hypothesis that the probability of a positive forecast error $(=(+) \mathrm{FE})$ is $50 \%$. For both the strong and the weak portfolio, we reject the null hypothesis at the $1 \%$ significance level. But, notice that (+)FE is smaller than $(-) \mathrm{FE}$ for the strong portfolio, while $(+) \mathrm{FE}$ is greater than (-)FE for the weak portfolio. This indicates that analyst optimism is more prevailing in the weak portfolio than in the strong portfolio. This is the first evidence that strong shareholder protection leads to lower analyst optimism.

Table 3: Nonparametric Binomial Test

This table summarizes a nonparametric binomial test of the null hypothesis that the probability $(p)$ of a positive forecast error $[(+)$ $F E]$ is 0.5 for all $n$ trials - i.e., Ho: $p=0.5$. Note that " $n$ " is the total number of positive and negative $F E$ s excluding zero $F E s$. Following Conover (1980; pp. 96-99), we calculate the test statistic $(T)$ and the corresponding critical regions at the 5\% and $1 \%$ levels as follows:

$$
\begin{aligned}
& T=\text { the number of }(+) F E s ; \\
& t 1 \_5 \%(\text { lower limit at the } 5 \% \text { level })=n p-1.96 \sqrt{n p(1-p)} ; \\
& t 2 \_5 \%(\text { upper limit at the } 5 \% \text { level })=n p+1.96 \sqrt{n p(1-p)} ; \\
& t 1 \_1 \%(\text { lower limit at the } 1 \% \text { level })=n p-2.58 \sqrt{n p(1-p)} ; \\
& t 2 \_1 \%(\text { upper limit at the } 1 \% \text { level })=n p+2.58 \sqrt{n p(1-p)} .
\end{aligned}
$$

\begin{tabular}{|c|c|c|c|c|c|c|c|c|c|}
\hline & $\mathbf{N}^{\mathrm{a}}$ & $(+) \mathrm{FE}^{\mathrm{a}}$ & $(-) F E^{a}$ & $\mathbf{n}^{\mathbf{a}}$ & $\mathbf{T}$ & t1_1\% & t2_1\% & t1_5\% & t2_5\% \\
\hline Strong & 36512 & 16086 & 16982 & 33068 & $16086^{* * *}$ & 16299 & 16769 & 16356 & 16712 \\
\hline Weak & 14247 & 6094 & 5489 & 11583 & $6094 * * *$ & 5653 & 5930 & 5686 & 5897 \\
\hline
\end{tabular}

${ }^{a} N$ includes zero $F E$ s, while $n$ does not. (+) FE is the number of positive forecast errors; (-) $F E$ is the number of negative forecast errors.

Table 4 shows the mean values of forecast errors $(F E)$, absolute forecast errors $(|F E|)$, and $I N F O$ over the sample period 1989 - 2003. Analyst optimism is, on average, prevalent in all years. All mean FEs are positive and significant at the $1 \%$ level. The results also suggest that the performance of analysts' forecasts dominates that of the naïve model. All mean INFOs are less than one and $73 \%$ of which are less than 0.5 . Both parametric and nonparametric correlation analysis presents a significant positive association between $F E$ and $|F E|$. This is consistent with a common belief that there is a negative relationship between forecast accuracy and optimism (Butler and Lang, 1991; Ackert and Athanassakos, 1997).

Results in Table 5 exhibit country-specific and portfolio-specific characteristics of analysts' forecasts. The mean FEs vary across countries, ranging from 0.043 (Switzerland) to 0.284 (Mexico). A rather striking observation is the widespread analyst optimism across countries. All mean FEs are significantly positive at the $1 \%$ level. In addition, in 14 of 19 countries, the percentage frequency of positive forecast errors (POS\%) is greater than $50 \%$.

The portfolio means of $F E,|F E|, I N F O$, and $P O S \%$ apparently contrast the strong portfolio with the weak. The mean $F E$ of the strong portfolio is 0.0892 , while the mean of the weak is 0.1239 . Both parametric (LeastSignificant-Difference; LSD) and non-parametric (Scheffé's) mean comparison tests indicate that the mean $F E$ difference between the strong and the weak portfolios is significant at the $1 \%$ level. The mean $|F E|$ of the strong portfolio (0.2111) is significantly smaller than that of the weak portfolio (0.2414). In addition, the mean POS\% of the strong portfolio $(48.65 \%)$ is lower than the mean of the weak portfolio $(52.61 \%)$. The country-mean and portfoliomean INFOs are all far smaller than one, suggesting that the superiority of analysts' forecasts against the naïve model prevails across countries, legal systems, and portfolios. 
Table 4: Yearly Means For FE, |FE|, And INFO

The table exhibits year-by-year means of FE, the absolute value of $F E(|F E|)$, and INFO. All terms are as defined in Table 2.

\begin{tabular}{|c|c|c|c|c|}
\hline & $\mathbf{N}$ & $\mathbf{F E}$ & $|\mathbf{F E}|$ & $\mathbf{I N F O}$ \\
\hline 1989 & 1025 & $0.0691 * * *$ & 0.1479 & 0.5589 \\
\hline 1990 & 1889 & $0.0792^{* * *}$ & 0.1621 & 0.4858 \\
\hline 1991 & 2268 & $0.0917 * * *$ & 0.1735 & 0.4493 \\
\hline 1992 & 2687 & $0.0886 * * *$ & 0.1831 & 0.4432 \\
\hline 1993 & 3102 & $0.0524 * * *$ & 0.1534 & 0.3941 \\
\hline 1994 & 3159 & $0.0679 * * *$ & 0.1797 & 0.4741 \\
\hline 1995 & 3402 & $0.0914 * * *$ & 0.1867 & 0.4625 \\
\hline 1996 & 3765 & $0.0744 * * *$ & 0.1938 & 0.4982 \\
\hline 1997 & 4233 & $0.0961 * * *$ & 0.2270 & 0.5546 \\
\hline 1998 & 4447 & $0.1526 * * *$ & 0.2724 & 0.4905 \\
\hline 1999 & 4427 & $0.1081 * * *$ & 0.2668 & 0.5368 \\
\hline 2000 & 4182 & $0.1323 * * *$ & 0.2787 & 0.5738 \\
\hline 2001 & 4221 & $0.1292^{* * *}$ & 0.2494 & 0.4894 \\
\hline 2003 & 4203 & $0.1055^{* * *}$ & 0.2428 & 0.4792 \\
\hline
\end{tabular}

Taken together, the strong portfolio is less optimistic and more accurate than the weak portfolio. As commonly observed in the U.S. studies, the evidence suggests that optimism is a dominant feature in international analysts' earnings forecasts. It is also observed that analysts have more accurate earnings forecasts than does the naïve model. As Errunza and Miller (2000), Reese and Weisbach (2002), Baker et al. (2002), and Lang et al. (2003) suggest, I test whether the removal of cross-listed firms from the analysis changes these results. I regenerate the statistics (not shown) for preliminary analysis and find that the removal of cross-listed firms does not alter the major findings.

\section{Regression Analysis}

Two regression models, equations (4) and (5), are employed to explain the relationships between shareholder protection and analyst optimism and between shareholder protection and analyst forecast accuracy controlling for time, industry, the number of analysts' forecasts, lagged forecast error (or lagged absolute forecast error), and standard deviation of earnings forecasts.

The Spearman correlation coefficient between time (years) and $F E$ is 0.52 and significant at the $5 \%$ level. The correlation coefficient between time and $|F E|$ is 0.84 , significant at the $1 \%$ level. Thus, controlling for time seems necessary. As in Lang et al. (2003), I also include industry dummies to control for possible industry effects. Ali and Hwang (2000) find that country-specific factors such as financial systems, the standard-setting process, tax rules, and external auditing services are significantly associated with the value relevance of financial accounting data. In this paper, the country effect is controlled by the portfolio dummy in the regression models. I add the number of analysts' forecasts, the lagged forecast error, and the standard deviation of earnings forecasts as control variables to account for the impact of analyst coverage, bias persistence, and forecast dispersion respectively. The regression models I estimate are as follows:

$$
\begin{aligned}
& F_{i, t}=a+b \text { PROTECT }_{i, t}+\sum_{s=1990}^{2003} c_{s} \text { Year }_{i, t, s}+\sum_{I=2}^{11} d_{I} I N D_{i, t, I}+F E_{i, t-1} \\
& + \text { PROTECT }_{i, t} * F E_{i, t-1}+N U M E S T_{i, t}+S T D_{i, t}+v_{i, t} \\
& |F E|_{i, t}=a+b \text { PROTECT }_{i, t}+\sum_{s=1990}^{2003} c_{s} \text { Year }_{i, t, s}+\sum_{I=2}^{11} d_{I} I N D_{i, t, I}+|F E|_{i, t-1} \\
& + \text { PROTECT }_{i, t} *|F E|_{i, t-1}+N U M E S T_{i, t}+S T D_{i, t}+v_{i, t}
\end{aligned}
$$


where $F E_{i, t}$ is the contemporaneous forecast error for observation $i$ in year $t ;|F E|_{\mathrm{i}, t}$ is the absolute value of the contemporaneous forecast error; $P R O T E C T_{i, t}$ is a binary variable equal to unity if an observation is classified in the strong shareholder-protected portfolio, and zero if classified as the weak portfolio; $Y E A R_{i, t, s}$ is a binary variable equal to unity if year $t$ equals $s$, zero otherwise; $I N D_{i, t, I}$ is a binary variable equal to unity if an observation belongs to industry $I$, zero otherwise; $F E_{i, t-1}\left(|F E|_{\mathrm{i}, t-1}\right)$ is the forecast error (absolute value of the forecast error) one year prior to the contemporaneous forecast error; $N U M E S T_{i, t}$ is the number of analysts' forecasts for observation $i$ in year $t$; and $S T D_{i, t}$ is the standard deviation among individual analysts' forecasts. The reference groups are the weak shareholderprotected portfolio, 1989, and industry 1 . Note that I use the I/B/E/S industry classification: industry 1 (finance) industry 11 (public utilities).

\section{Table 5: Country-By-Country Statistics Of FE, |FE|, And INFO}

This table exhibits the portfolio and country-by-country means of FE, the absolute value of $F E(|F E|), I N F O$, and $P O S \%$. All terms are as defined in Table 2.

\begin{tabular}{|c|c|c|c|c|c|}
\hline Portfolio & Countries & FE & $\mid$ FE & INFO & POS\%a \\
\hline \multirow{10}{*}{ Strong } & Canada & $0.1103^{* * *}$ & 0.2623 & 0.5405 & 49.56 \\
\hline & Chile & $0.1486^{* * *}$ & 0.2260 & 0.6196 & 62.10 \\
\hline & Hong Kong & $0.1662 * * *$ & 0.2463 & 0.5919 & 59.39 \\
\hline & India & $0.0680 * * *$ & 0.1685 & 0.5865 & 51.67 \\
\hline & Japan & $0.0808^{* * *}$ & 0.2161 & 0.4344 & 50.21 \\
\hline & Malaysia & $0.1107 * * *$ & 0.2267 & 0.4686 & 46.69 \\
\hline & Singapore & $0.1149 * * *$ & 0.2234 & 0.4873 & 50.97 \\
\hline & South Africa & $0.0736 * * *$ & 0.1760 & 0.5412 & 51.38 \\
\hline & UK & $0.0691 * * *$ & 0.1735 & 0.5176 & 42.05 \\
\hline & Portfolio Mean & $0.0892^{\mathrm{a}}$ & $0.2100^{\mathrm{a}}$ & 0.4933 & 48.65 \\
\hline \multirow{11}{*}{ Weak } & Austria & $0.1132 * * *$ & 0.2111 & 0.4009 & 53.38 \\
\hline & Belgium & $0.1116^{* * *}$ & 0.2226 & 0.5448 & 55.43 \\
\hline & Denmark & $0.0809 * * *$ & 0.1945 & 0.4337 & 50.53 \\
\hline & Germany & $0.1149 * * *$ & 0.2247 & 0.4782 & 54.32 \\
\hline & Indonesia & $0.2069 * * *$ & 0.3135 & 0.5237 & 56.69 \\
\hline & Italy & $0.1493 * * *$ & 0.2968 & 0.6161 & 52.81 \\
\hline & Mexico & $0.2841 * * *$ & 0.4436 & 0.7982 & 56.24 \\
\hline & Netherlands & $0.0692 * * *$ & 0.1576 & 0.3971 & 48.45 \\
\hline & Switzerland & $0.0429 * * *$ & 0.1602 & 0.4779 & 47.58 \\
\hline & Turkey & $0.1823 * * *$ & 0.3120 & 0.4569 & 54.91 \\
\hline & Portfolio Mean & $0.1239^{\mathrm{a}}$ & $0.2414^{\mathrm{a}}$ & 0.4972 & 52.61 \\
\hline
\end{tabular}

${ }^{a}$ Both parametric (LSD) and non-parametric (Scheffe's) pair-wise comparison tests indicate that the mean differences between the strong and the weak portfolios are significant at the $1 \%$ level.

* significant at the $10 \%$ level. ** significant at the $5 \%$ level. *** significant at the $1 \%$ level.

The regression results support the findings reported in the previous section. The coefficient of PROTECT is significantly negative at the $1 \%$ level for both models. This indicates that strong shareholder protection reduces the optimistic tendency in analysts' earnings forecasts and enhances their forecasting ability. The data also show that there are significant year and industry effects on $F E$ and $|F E|$. 


\section{Table 6: Mean Comparisons Between High And Low Portfolios Within Indicators}

The table (See next page.) contains parameter estimates and associated p-levels for two regression models estimated over the subset of observations in strong and weak shareholder-protected countries:

where $F E_{i, t}$ is the contemporaneous forecast error for observation $i$ in year $t ;|F E|_{\mathrm{i}, t}$ is the absolute value of the contemporaneous forecast error; PROTECT $T_{i, t}$ is a binary variable equal to unity if an observation is classified in the strong shareholder-protected portfolio, and zero if classified as the weak portfolio; $Y E A R_{i, t, s}$ is a binary variable equal to unity if year $t$ equals $s$, zero otherwise; $I N D_{i, t, I}$ is a binary variable equal to unity if an observation belongs to industry $I$, zero otherwise; $F E_{i, t-I}\left(|F E|_{i, t-I}\right)$ is the forecast error (absolute value of the forecast error) one year prior to the contemporaneous forecast error; $N U M E S T_{i, t}$ is the number of analysts' forecasts for observation $i$ in year $t$; and $S T D_{i, t}$ is the standard deviation among individual analysts' forecasts. The reference groups are the weak shareholder-protected portfolio, 1989, and industry 1 . Note that $\mathrm{I}$ use the $\mathrm{I} / \mathrm{B} / \mathrm{E} / \mathrm{S}$ industry classification: industry 1 (finance) industry 11 (public utilities).

\begin{tabular}{|c|c|c|}
\hline \multirow[t]{2}{*}{ Variable } & \multicolumn{2}{|c|}{ Coefficient } \\
\hline & Equation (4) & Equation (5) \\
\hline Intercept & $0.11405 * * *$ & $0.19317 * * *$ \\
\hline PROTECT & $-0.03881 * * *$ & $-0.04823 * * *$ \\
\hline YEAR90 & 0.00723 & 0.01079 \\
\hline YEAR91 & 0.02177 & 0.02906 \\
\hline YEAR92 & 0.02134 & $0.04648 * *$ \\
\hline YEAR93 & -0.01614 & 0.01845 \\
\hline YEAR94 & -0.00446 & $0.03368 *$ \\
\hline YEAR95 & 0.02128 & $0.04808^{* *}$ \\
\hline YEAR96 & 0.00485 & $0.04699 * *$ \\
\hline YEAR97 & 0.02642 & $0.08276^{* * *}$ \\
\hline YEAR98 & $0.08134 * * *$ & $0.12823 * * *$ \\
\hline YEAR99 & 0.02592 & $0.09669 * * *$ \\
\hline YEAR00 & $0.07490 * * *$ & $0.13822 * * *$ \\
\hline YEAR01 & $0.06951 * * *$ & $0.11358 * * *$ \\
\hline YEAR02 & $0.06735 * * *$ & $0.14321 * * *$ \\
\hline YEAR03 & 0.01947 & $0.09617 * * *$ \\
\hline $\mathrm{IND}_{2}$ - Health Care & $-0.06037 * * *$ & $-0.06943 * * *$ \\
\hline $\mathrm{IND}_{3}$ - Consumer Non-Durables & 0.00146 & -0.01016 \\
\hline $\mathrm{IND}_{4}$ - Consumer Services & 0.01247 & 0.01151 \\
\hline IND5 - Consumer Durables & $-0.02890 *$ & -0.01395 \\
\hline IND6 - Energy & $0.04578 * * *$ & $0.08382 * * *$ \\
\hline $\mathrm{IND}_{7}$ - Transportation & -0.00253 & 0.02672 \\
\hline $\mathrm{IND}_{8}-$ Technology & 0.00643 & $0.03512 * * *$ \\
\hline $\mathrm{IND}_{9}$ - Basic Industries & 0.00477 & $0.03064 * * *$ \\
\hline IND10 - Capital Goods & $-0.02092 * *$ & $-0.01817 * *$ \\
\hline IND $_{11}$ - Public Utilities & $-0.02912 *$ & $-0.02481 *$ \\
\hline $\mathrm{FE}_{\mathrm{i}, \mathrm{t}-1}\left(|\mathrm{FE}|_{\mathrm{i}, \mathrm{t}-1}\right)$ & -0.000008 & 0.000002 \\
\hline PROTECT* $^{*} \mathrm{FE}_{\mathrm{i}, \mathrm{t}-1}\left(|\mathrm{FE}|_{\mathrm{i}, \mathrm{t}-1}\right)$ & $0.000753 *$ & $0.000649 *$ \\
\hline NUMEST & $-0.00349 * * *$ & $-0.00571 * * *$ \\
\hline STD & $0.000008 * *$ & $0.000007 * *$ \\
\hline Adjusted R-square & 0.0057 & 0.0137 \\
\hline Number of Observations & 50707 & 50707 \\
\hline
\end{tabular}

\footnotetext{
*** Significant at the $1 \%$ level. ** Significant at the 5\% level. * Significant at the $10 \%$ level.
} 
A positive correlation between $F E_{i, t}$ and $F E_{i, t-1}$ is not observed for the weak portfolio. This result is not consistent with the evidence reported by Mendenhall (1991), Abarbanell and Bernard (1992), and Ali, Klein, and Rosenfeld (1992) for the domestic case. The coefficient of $F E_{i, t-1}$ is statistically equal to zero. The same is true for the coefficient of $|F E|_{i, t-1}$. However, for the strong portfolio, the corresponding coefficients are significantly positive at the $1 \%$ level. The coefficient of $F E_{i, t-l}$ for the strong portfolio is the sum of the coefficient of $F E_{i, t-1}$ for the weak and the coefficient of the interaction term in equation (4). It is positive and significant at the $1 \%$ level. Similarly, the coefficient of $|F E|_{i, t-1}$ for the strong portfolio is significantly positive at the $1 \%$ level. The positive coefficients of $F E_{i, t-}$ $l$ and $|F E|_{i, t-l}$ for the strong portfolio imply that analysts working in strong shareholder-protected countries tend to underreact to new earnings information, since the coefficients of $F E_{i, t-1}$ and $|F E|_{i, t-1}$ should not be significant if analysts fully incorporate the earnings information released a year prior to the contemporaneous year (Easterwood and Nutt , 1999). When analysts indeed underreacted to new earnings information at its inception, they would adjust for the underreaction over time and the adjustment would be manifested in the positive coefficient of $F E_{i, t-1}$ and/or $|F E|_{i, t-1}$.

The coefficients of NUMEST for both models are -0.00349 and -0.00571 . They are significant at the $1 \%$ level, suggesting that an increase in analyst coverage reduces analyst optimism and improves forecast accuracy. This finding is not surprising, since analyst coverage proxies private information acquisition (Barron and Stuerke, 1998). As the forecast dispersion (STD) increases, analyst optimism becomes more serious and forecast accuracy deteriorates. This positive association is significant at the 5\% level. Similar results (not reported here) are observed when excluding cross-listed firms from the sample.

\section{CONCLUSIONS AND SUGGESTIONS FOR FUTURE RESEARCH}

The paper relates analyst forecast bias to shareholder protection in a global setting. As commonly observed in U.S. analysts' earnings forecasts, analyst optimism characterizes analysts' earnings forecasts in many foreign countries. Country-specific mean forecast errors are all significantly positive at the $1 \%$ level. In addition, in 14 of 19 countries, the percentage frequency of analyst optimism is greater than $50 \%$. Consistent with prior U.S. studies, the data also suggest that the superiority of analysts' forecasts against the naïve model prevails across countries and portfolios. Both parametric and non-parametric correlation analyses present a significant positive association between $F E$ and $|F E|$. This is consistent with a common belief that there is a negative relationship between forecast accuracy and optimism.

Results reveal that analysts' forecasts issued in countries with strong shareholder protection laws are less optimistic and more accurate than analysts' forecasts published in countries with weak protection laws. In the strong shareholder-protected countries, analysts' underreaction to earnings information is observed. Results also present significant effects of year, industry, bias persistence, analyst coverage, and forecast dispersion. The elimination of cross-listed firms does not change these conclusions. Another interesting observation is the high percentage of zero forecast errors across countries, suggesting widespread practice of earnings management.

The current study provides evidence that analysts under different shareholder protection systems display distinctive characteristics of forecast bias. Thus, future research on the market reaction to such idiosyncratic forecast bias is warranted. It would be interesting to see how differently investors take new earnings news when they are subject to different shareholder protection systems.

\section{REFERENCES}

1. Abarbanell, Jeffery S., Do analysts' earnings forecasts incorporate information in prior stock price changes?, Journal of Accounting and Economics, Vol. 14, No. 2, pp. 147-165, 1991.

2. Abarbanell, Jeffery S. and Victor L. Bernard, Tests of analysts' overreaction / underreaction to earnings information as an explanation for anomalous stock price behavior, Journal of Finance, Vol. 47, No. 3, pp. 1181-1207, 1992.

3. Ackert, Lucy F. and George Athanassakos, Prior uncertainty, analyst bias, and subsequent abnormal returns, Journal of Financial Research, Vol. 20, No. 2, pp. 263-273, 1997. 
4. Ali, Ashiq, April Klein, and James Rosenfeld, Analysts' use of information about permanent and transitory earnings components in forecasting annual EPS, Accounting Review, Vol. 67, No. 1, pp. 183-198, 1992.

5. Ali, Ashiq and Lee-Seok Hwang, Country-specific factors related to financial reporting and the value relevance of accounting data, Journal of Accounting Research, Vol. 38, No. 1, pp. 1-21, 2000.

6. Ang, James S. and Yulong Ma, Transparency in Chinese stocks: A study of earnings forecasts by professional analysts, Pacific-Basin Finance Journal, Vol. 7, No. 2, pp. 129-155, 1999.

7. Baker, H. Kent, John R. Nofsinger, and Daniel G. Weaver, International cross-listing and visibility, Journal of Financial and Quantitative Analysis, Vol. 37, No. 3, pp. 495-521, 2002.

8. Barron, Orie E. and Pamela S. Stuerke, Dispersion in analysts' earnings forecasts as a measure of uncertainty, Journal of Accounting, Auditing \& Finance, Vol. 13, No. 3, pp. 245-270, 1998.

9. Butler, Kirt C. and Larry H. P. Lang, The forecast accuracy of individual analysts: Evidence of systematic optimism and pessimism, Journal of Accounting Research, Vol. 29, No. 1, pp. 150-156, 1991.

10. Conover, W. J., Practical nonparametric statistics 2ed, John Wiley \& Sons, Inc., New York, 1980.

11. Degeorge, François, Jayendu Patel, and Richard Zeckhauser, Earnings management to exceed thresholds, Journal of Business, Vol. 72, No. 1, pp. 1-33, 1999.

12. Easterwood, John C. and Stacey R. Nutt, Inefficiency in analysts' earnings forecasts: Systematic misreaction or systematic optimism?, Journal of Finance, Vol. 54, No. 5, pp. 1777-1797, 1999.

13. Errunza, Vihang R. and Darius P. Miller, Market segmentation and the cost of capital in international equity markets, Journal of Financial and Quantitative Analysis, Vol. 35, No. 4, pp. 577-600, 2000.

14. Hope, Ole-Kristian, Disclosure practices, enforcement of accounting standards, and analysts' forecast accuracy: An international study, Journal of Accounting Research, Vol. 41, No. 2, pp. 235-272, 2003.

15. Hung, M., Accounting standards and value relevance of earnings: An international analysis, Journal of Accounting and Economics, Vol. 30, No. 3, pp. 401-420, 2001.

16. Keane, M. and D. Runkle, Are financial analysts' forecasts of corporate profits rational?, Journal of Political Economy, Vol., No. 4, pp. 768-805, 1998.

17. Kwag, Seung-Woog (Austin) and Ronald E. Shrieves, Chronic Bias in analysts' earnings forecasts, forthcoming in Financial Analysts Journal, 2005.

18. La Porta, Rafael, Expectations and the cross-section of stock returns, Journal of Finance, Vol. 51, No. 5, pp. 1715-1742, 1996.

19. La Porta, Rafael, Florencio Lopez-De-Silanes, Andrei Shleifer, and Robert W. Vishny, Law and Finance, Journal of Political Economy, Vol. 106, No. 6, pp. 1113-1155, 1998.

20. Lang, Mark H., Karl V. Lins, and Darius P. Miller, ADRs, analysts, and accuracy: Does cross listings in the U.S. improve a firm's information environment and increase market value?, Journal of Accounting Research, Vol. 41, No. 2, pp. 317-345, 2003.

21. Mendenhall, R., Evidence of the possible underweighting of earnings-related information, Journal of Accounting Research, Vol. 29, No. 1, pp. 170-180, 1991.

22. O'Brien, P., Analysts' Forecasts as Earnings Expectations. Journal of Accounting and Economics, Vol. 10, No. 1, pp. 53-83, 1988.

23. Reese Jr., William A. and Michael S. Weisbach, Protection of minority shareholder interests, cross-listings in the United States, and subsequent equity offerings, Journal of Financial Economics, Vol. 66, No. 1, pp. 65$104,2002$. 